\title{
Spatio-temporal analyses of local biodiversity hotspots reveal the importance of historical land-use dynamics
}

\author{
Anda Fescenko ${ }^{1,2,3} \cdot$ Thomas Wohlgemuth $^{1}$
}

Received: 15 April 2016/Revised: 19 March 2017/Accepted: 14 May 2017/

Published online: 20 May 2017

(C) Springer Science+Business Media Dordrecht 2017

\begin{abstract}
Woodland key habitats (WKHs) form a network of local biodiversity hotspots in human-dominated landscapes of northern Europe. They have been designated based on the presence of old-growth species and structures, and are considered to indicate long-term forest cover. To test whether WKHs do particularly occur in continuous forest land and to explore the scale dependence of relationships between WKH presence and their historical and environmental properties, we analysed them at five spatial scales (from stand to landscape: 80-2500 m) and referring to four reference years $(1790,1860,1910$, and 2010) using univariate and multivariate analyses. We upscaled the georeferenced data using a moving window approach. The study area encompassed 94,886 contiguous forest stands in a boreo-nemoral region of southern Latvia $\left(5178 \mathrm{~km}^{2}\right)$ with a relatively short history of intensive land use. At the scale of stands, the presence of WKHs, ranging from 0.1 to 59 ha in size, best corresponded to highly variable land-use histories 100-220 years ago such as natural succession on abandoned land, drained bogs and wetlands, and only partly to continuous forest cover for more than 220 years. We identified short-term (50-70 years) and small-scale (up to $250 \mathrm{~m}$ ) gaps in past forest cover as significant positive predictors of WKH presence, which resemble patterns caused by natural disturbances. At broader scales $(800-2500 \mathrm{~m})$, best explanatory variables were the presence of old forest fragments throughout the landscape, at least 100 years of continuous forest cover, changes in forest cover, i.e., afforestation, between 1790 and 1860, and the proximity to bogs and rivers. We
\end{abstract}

Communicated by Daniel Sanchez Mata.

Electronic supplementary material The online version of this article (doi:10.1007/s10531-017-1366-0) contains supplementary material, which is available to authorized users.

Anda Fescenko

andafes@gmail.com

1 Forest Dynamics Unit, Swiss Federal Research Institute WSL, Zürcherstrasse 111, 8903 Birmensdorf, Switzerland

2 Faculty of Biology, University of Latvia, Jelgavas 1, Riga 1004, Latvia

3 Latvian State Forest Research Institute 'Silava', Rigas Street 111, Salaspils, Riga 2169, Latvia 
also found that correlations between WKH presence and forest patch density converted from negative coefficients at small spatio-temporal scales to positive ones at broader spatio-temporal scales. Our results highlight the importance of using multi-scale information on land-use history to improve both the understanding and the management of biodiversity in cultural landscapes. In brief, instead of long-term continuous forest cover, we found a surprisingly diverse and dynamic land-use history in places that have been designated as WKHs.

Keywords Biodiversity conservation · Forest continuity $\cdot$ Land-use changes · Moving window approach $\cdot$ Scale dependence $\cdot$ Spatial and temporal scales $\cdot$ Temporal heterogeneity · Woodland key habitats

\section{Introduction}

Biodiversity has evolved from continuous interactions between species and the environment in space and time (Palmer and Maurer 1997). Accordingly, nature conservation should be based on the understanding of spatio-temporal processes (Lindenmayer et al. 2006; Graham et al. 2010; Cadotte et al. 2017), which implies a profound knowledge of the longevity of species habitats. Land-use changes over the past centuries have become the most severe driver affecting biodiversity in Europe and globally (Sala et al. 2000; Foley et al. 2005; Amici et al. 2015). To preserve species diversity in the fast-changing landscape (Luginbühl and Howard 2016), it is important to investigate key factors and scales that determine the relationship between the fluctuating patterns of habitats over time and the continuation of biodiversity (Wu and Hobbs 2002; Li and Wu 2004; Graham et al. 2010).

The majority of studies on the role of landscape pattern on species diversity have focused on the spatial dimension. Temporal aspects, such as land-use changes over centuries, have not been examined with the same intensity, mainly due to the absence of extensive historical information on habitats and species (Ernoult et al. 2006). Many studies have shown a clear correspondence between present landscape features and species richness (e.g., Dufour et al. 2006; Franc et al. 2007; Widerberg et al. 2012, Bailey et al. 2017). The latter parameter may correlate just as well or even better with past land uses, given species-specific time lags between environmental changes and subsequent species dynamics (Ernoult et al. 2006; Metzger et al. 2009; Schneider 2009). Relatively few studies have linked single species or species groups diversity with historical land-use changes (e.g., Gerhardt and Foster 2002; Lindborg and Eriksson 2004; Fritz et al. 2008; Josefsson et al. 2010), and little is known about multi-scale effects of past land use on local biodiversity hotspot areas in general. In this respect, the concept of panarchy of complex systems of people and nature (Holling 2001) is increasingly addressed. However, quantitative analyses across scales of space and time are widely missing (Allen et al. 2014; Angeler et al. 2016).

Woodland key habitats (WKHs) form a network of small and dispersed stands with high biodiversity value in the landscape of intensively managed forests in northern Europe (Timonen et al. 2010). We chose WKHs as a proxy of local biodiversity hotspots based on the following facts: (1) WKHs are considered natural or semi-natural forest remnants that are rich in both structures and species (Perhans et al. 2007; Ikauniece et al. 2012); (2) WKHs contain old-growth dependent species, mainly flowering plants, bryophytes, 
lichens, fungi, insects and molluscs, all of which are unable to survive in frequently logged stands (see Ek et al. 2002 for a species list; Perhans et al. 2007; Timonen et al. 2010); (3) WKHs are small, i.e. the mean area varies from 0.7 ha in Finland to 4.6 ha in Sweden (Timonen et al. 2010), and unevenly dispersed within a dynamically managed landscape with a diverse land-use history. In the Baltic region, in particular in Latvia, intensive land use started relatively late compared to other European countries because of a low population density; therefore, the period of rapid depletion of forests lagged far behind similar processes in western Europe (Dunsdorf and Spekke 1964; von Rauch 1970). By the end of the 17th century, forest cover in Latvia still amounted to $65 \%$ of the total area (Zunde 1999; Kaplan et al. 2009). The rapid development of agriculture and industry in the 18th and 19th centuries resulted in the lowest level of forest area (24\%) in the 1920s. As a result, the landscape in the region became highly fragmented. Forest cover doubled again by 2012 (55\%; State Forest Service 2012). This suggests that almost half of the contemporary forests grows on recently abandoned agricultural land, even though the period of deforestation was rather short. These recent short-term transformations raise questions: How crucial such land-use changes are for WKH species with specific habitat requirements? What factors drive the formation of local biodiversity hotspots? Whether the importance of these factors changes across scales?

To answer these questions we analysed a comprehensive land-use inventory dataset containing information on 94,886 contiguous forest stands in the landscape of Zemgale, Latvia $\left(5178 \mathrm{~km}^{2}\right)$, which has experienced intensive land-use changes over the last three centuries (Zunde 1999; Fescenko et al. 2014) and nevertheless has a relatively high percentage of WKHs (3.8\%; State Forest Service 2010). Since changes in biodiversity cannot be satisfactorily measured by the abundance of a single taxon or a single functional group (Noss 1990; Ernoult et al. 2006), and since there is no 'right' scale for analysing processes in species dynamics (Götmark et al. 2008; Boscolo and Metzger 2009), we used WKHs and their historical and environmental properties across five spatial scales, i.e., from stands (neighbourhood radius $r_{\mathrm{n}}=80 \mathrm{~m}$ ) to landscapes $\left(r_{\mathrm{n}}=2500 \mathrm{~m}\right.$ ). In all scales, we used WKH presence/absence as a binomial response variable and historical and environmental variables as predictor variables. We hypothesized that (1) land-use history, in particular long-term forest continuity, is the most important predictor of the presence of WKHs, and (2) the predictive value of variables is scale-dependent.

\section{Methods}

\section{Study area}

The Zemgale region in Latvia (Fig. 1) is located in the boreo-nemoral vegetation zone, where boreal coniferous forests are mixed with nemoral deciduous forests (Hytteborn et al. 2005). The mean annual temperature is 5.0-5.2 ${ }^{\circ} \mathrm{C}(1925-2006$; Lizuma et al. 2007) and the mean annual precipitation is 670-700 mm (1925-2006; Lizuma et al. 2010). All forests cover $31 \%$ of the study area of $5178 \mathrm{~km}^{2}$ (State Forest Service 2010). Most of Zemgale is flat, and the elevation ranges from 20 to $60 \mathrm{~m}$ a.s.l. The region contains a dense network of streams and rivers running into the Gulf of Riga in the Baltic Sea via the Lielupe river. Fertile soils formed from Baltic Ice Lake sediments prompted the development of agriculture in the central and southern parts of the study area. In the western part, soils on moderately calcareous deposits are found. Due to differences in the substrate, forests are 


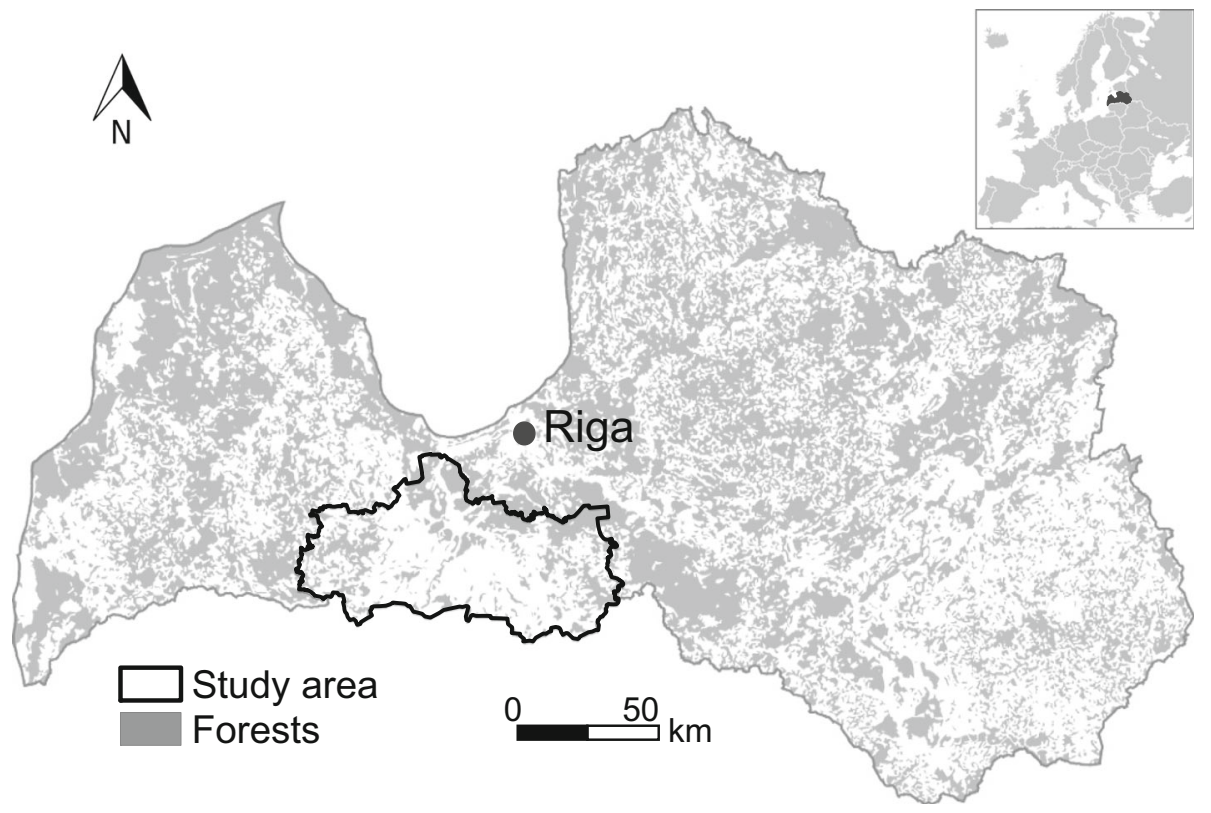

Fig. 1 Location of the study area Zemgale and distribution of forests in Latvia

not evenly distributed (Fig. 1). A mosaic of woodland and agricultural land is characteristic of both the western and the eastern parts of the study area. In the north, contiguous boreal forests prevail on sandy soils. Dominant tree species are Scots pine (Pinus sylvestris), Norway spruce (Picea abies), silver birch (Betula pendula), common aspen (Populus tremula), grey alder (Alnus incana) and black alder (A. glutinosa). Stands with nemoral deciduous tree species are relatively rare. A few centuries ago, these tree species, e.g., pedunculate oak (Quercus robur), common ash (Fraxinus excelsior), small-leaved lime (Tilia cordata) and Scots elm (Ulmus glabra), were characteristic of the region (Zunde 1999). All forests are generally managed in three ways: protected forests (banned from logging activities), forests with restricted management (banned from clear-cuts), and exploitable forests (clear-cutting is allowed). In the Zemgale region, $10.7 \%$ of the all forested area is protected and one third of the protected forests $(3.8 \%$ of the total forested area) is designated as WKHs. The size of the WKHs in the study area ranges from 0.1 to 59 ha with a mean area of 2.1 ha (State Forest Service 2010).

\section{Data sources}

We used data from four sources: (1) State Forest Service database (SFS, including both state and private forests; State Forest Service 2010), which consists of 110,647 contiguous georeferenced polygons with a total area of 517,800 ha, depicting the present land uses (forest, wetland, shrub cover, crop field, and others), and the distribution of forest stands. Available attributes included growing conditions, tree species composition and age, management, protection regime, and the WKH status for each forest stand. A forest stand was defined as the smallest forest management unit (minimum size 0.1 ha) with relatively homogeneous tree species composition, age and growing conditions. A total of 94,886 polygons contained such forest stands. (2) GIS Latvia 10 geo-database (GISL; Envirotech 
2013) was used to determine environmental variables including landscape elements, such as rivers, roads, bogs, villages, as well as elevation. (3) European Soil Database (SOIL; European Soil Database 2013) was used to identify soil variables according to FAO90. (4) The digital forest continuity map of Zemgale (see Fescenko et al. 2014 for details) was composed previously from the Latvian army map (1910, scale 1:75,000), the military topographical map of European Russia (1860, scale 1:126,000) and the Karte von Kurland von C. Neumann (1790, scale 1:296,000; see Online Resource 1), and included the distribution of forests during the last three centuries. In military cartography, land dominated by trees is commonly treated as forest (Fescenko et al. 2016).

\section{Response variable}

Based on the field inventory of Ek et al. (2002), the presence of 2797 WKHs served as the response variable (Table 1; Online Resource 2). Vegetation in the WKHs of the Zemgale region encompassed 15 out of 20 defined vegetation types for forests in Latvia (Ek et al. 2002) and represented all native forest habitats in this region. For analysing forest continuity at the stand scale, we subdivided the WKHs into four coarse forest vegetation classes (Braun-Blanquet 1964): (1) Boreal forests with Scots pine, mixed coniferous-deciduous forests, pine-birch wetland forests,- - all dominated by Pinus silvestris and Picea abies, (2) nemoral forests with broad-leaved species Quercus robur, Fraxinus excelsior, Tilia cordata, and Ulmus glabra, (3) black alder wetland forests, (4) early successional forests with aspen and other deciduous species, dominated by Betula pendula, Populus tremula. In all models and scales, we used presence/absence of a WKH as a binomial response variable. For landscape scales, binomial data were derived from the accumulated area of WKHs using thresholds (Table 1).

Table 1 Characteristics of the spatial extent of the datasets and woodland key habitats (WKHs)

\begin{tabular}{|c|c|c|c|c|c|c|}
\hline \multirow[t]{2}{*}{ Characteristics } & \multirow{2}{*}{$\begin{array}{l}\text { Stand } \\
\text { S0 }\end{array}$} & \multicolumn{5}{|c|}{ Landscape scales } \\
\hline & & $\mathrm{S} 1$ & $\mathrm{~S} 2$ & $\mathrm{~S} 3$ & $\mathrm{~S} 4$ & S5 \\
\hline \multicolumn{7}{|l|}{ Spatial extent } \\
\hline Number of $500 \times 500 \mathrm{~m}$ cells & - & 1 & 9 & 25 & 89 & 413 \\
\hline Area (ha) & 2.1 & 25 & 225 & 625 & 2225 & 10,325 \\
\hline$r_{\mathrm{n}}$, rounded $(\mathrm{m})$ & $80 *$ & 250 & 800 & 1400 & 2500 & 5500 \\
\hline Threshold for outliers (ha), (\%) & 0.1 & 0.4 & 0.044 & 0.016 & 0.005 & 0.001 \\
\hline \multicolumn{7}{|l|}{ Number of sample units } \\
\hline With WKHs & 2797 & 2135 & 6264 & 9779 & 15,768 & 20,828 \\
\hline All forests & 94,886 & 12,815 & 18,542 & 20,463 & 21,285 & 21,303 \\
\hline \multicolumn{7}{|c|}{ Number of sample units selected for $\mathrm{n}=100$ permutations } \\
\hline Subsets with WKHs & \multicolumn{6}{|c|}{ Each 1850} \\
\hline Subsets with no WKHs & \multicolumn{6}{|c|}{ Each 1850} \\
\hline
\end{tabular}

$r_{n}$-radius of neighbourhood

* Scale S0 indicates the stand level with a mean stand area of 2.1 ha, corresponding to a circle radius of $80 \mathrm{~m}$ 


\section{Predictor variables}

We classified predictor variables as historical and environmental (see Online Resource 2). Historical variables were obtained from the digital forest continuity map of Zemgale with four reference years $t_{\mathrm{x}}=\{2010,1910,1860,1790\}$. Continuity of forest land use (hereafter, forest continuity, variable CONT) referred to constant forest use over time, including woodlands that were partially cleared if reforested immediately (Westphal et al. 2004). Forest continuity was subdivided into four classes: forest (1) for less than 100 years, (2) for a period of 100-149 years, (3) for a period of 150-220 years, and (4) for longer than 220 years. The percentage of forest cover at a given reference time $S(t)$ was expressed by variables F2010, F1910, F1860, and F1790. Forest cover changes were calculated by the equation $C H x(x+1)=S\left(t_{x}\right)-S\left(t_{x+1}\right)$, where $x$ was the ordinal number of the reference year, and resulted in variables $\mathrm{CH} 12, \mathrm{CH} 23$ and $\mathrm{CH} 34$. To address historical fragmentation of forests at the landscape, we defined two sets of variables: number of forest patches $N P(t)$ with variables NP2010, NP1910, NP1860, and NP1790, and forest patch density $N P(t) / S(t)$ with variables PD2010, PD1910, PD1860, and PD1790.

Environmental variables contained information on stand (a) and landscape (b) structure. Stand data (a) provided information on growing conditions (dry mineral soils DRY-MIN, wet mineral soils WET-MIN, wet peatlands WET-PEAT); tree species composition and the presence of old forests (OLDF); cutting, burning or windthrow during the last 20 years (forest disturbances, DISTUR); and presence of ditches in a stand (DRAIND). The dominant tree species in each stand was defined as the one having the largest relative volume. Stand age $\left(\right.$ age $\left._{\mathrm{dom}}\right)$ was defined from the SFS database as the average age of the dominant tree species. Old forests corresponded to stands with $a g e_{\text {dom }}$ of more than 100 years for deciduous species and more than 120 years for coniferous species. Tree species richness within the stand (TRICH) was derived from the SFS database, taking into account all tree species including individual trees. Landscape data (b) were used to integrate information about landscape structure and spatial heterogeneity: length of roads (ROADS), length of forest rivers and streams (RIVERS), proximity of large bogs (BOGS), proximity of forest glades (GLADES), distance of the nearest village (VILL), elevation above sea level (ELEV). A set of 13 types of soils derived from the SOIL database was reduced to two variables describing soil wetness (SWET) and fertility (SRICH), following Kasparinskis and Nikodemus (2012). In total, 33 predictor variables were defined (see full list of variables in Online Resource 2).

\section{Data processing and analysis}

Predictor variables derived from data sources 2-4 (maps) were assigned to stand polygons by digital intersection, with values defined according to the top ranked area per polygon. Dummy variables with values presented in less than $1 \%$ of stands were excluded. All data relevant for WKH stands represented the dataset S0 (stand scale). The study area was then gridded using $500 \times 500 \mathrm{~m}$ cells $(25$ ha in area; $\mathrm{n}=21,303)$, which served as the basis for landscape level analyses (scales S1-S4). Intersecting digital maps and WKHs with this grid resulted in a new set of variables defining a WKH as a single grid-cell (S1; smallest landscape scale) with attributed landscape properties. Grid-cell properties were scaled up to broader landscape scales (S2-S4) by neighbourhood analysis using the moving window algorithm (ArcGIS ModelBuilder tool). Circular windows with neighbourhood radii $\left(r_{\mathrm{n}}\right)$ of 800,1400 , and 2500 meters were moved through the grid, assigning each cell the 
aggregation of variables (classes, sums, averages and standard deviations) of the cells that overlapped (partially or completely) with the window (Table 1; Online Resource 3). The radii $r_{\mathrm{n}}=80 \mathrm{~m}$ for scale $\mathrm{S} 0$ and $r_{\mathrm{n}}=250 \mathrm{~m}$ for scale $\mathrm{S} 1$ were derived from the mean stand area and the grid-cell area, respectively. Window sizes at scales S1 and S4 were chosen by adopting the mean size of forest patches $(\approx \mathrm{S} 1)$ and forest tracts $(\approx \mathrm{S} 4)$ of the study area. Intermediate scales $\mathrm{S} 2$ and $\mathrm{S} 3$ were defined in relation to area sizes of S1: $2 r_{\mathrm{n}}$ for scale $\mathrm{S} 2$ was three square sides of $\mathrm{S} 1$, and $2 r_{\mathrm{n}}$ for scale $\mathrm{S} 3$-five square sides of $\mathrm{S} 1$ (see Online Resource 3$)$. An additional landscape scale S5 ( $r_{\mathrm{n}}=5500$ meters) was used only to determine the limits approached by the studied quantities. All spatial analyses were performed using ArcGIS version 10.1.

Pearson correlation coefficients were calculated scalewise between all variables. Since the number of WKHs was small and the number of cells with WKH presences varied depending on the scale (2135-20,828 units; Table 1), we randomly selected $n=100$ subsets of data, each consisting of two parts: one containing 1850 cells or stands (hereafter, samples) with WKHs and one with the same number of samples lacking WKHs. The resulting datasets, 100 per scale S0-S4, consisted of 3700 sample units each and were used for further analyses.

Generalized Linear Models (GLM; McCullagh and Nelder 1989; Bolker et al. 2009) were fitted to analyse the relationship between WKH presence and refined sets of variables at different scales. To reduce the large number of initial variables $(n=239)$, collinearities among the variables for each dataset were analysed beforehand. Hierarchical clustering (Ward's method) was applied with distance matrix $D=1-A b s$ (correlation matrix) to select groups of highly correlated variables (threshold distance: 0.55 ). Groups of two or more highly correlated variables $\left(r^{2}>0.7\right)$ were defined and all variables there within were tested one by one with negative binomial GLM (glm.nb; package MASS; Venables and Ripley 2013) for best correlations with WKHs. The negative binomial GLM was applied because data were over-dispersed. The variables with the best model fit according to Akaike's Information Criterion (AIC; Venables and Ripley 2013) were selected for further multivariate analysis. In the models, we used only linear terms of the variables. Preliminary model runs including quadratic terms did not improve the model performance. All possible triplet combinations of predictor variables were tested for best model performances by comparing resulting AICs. Additional variables were then integrated stepwise, choosing the best model at each step, until the change in explained deviance $D^{2}$ was less than 1\% (Schwarz and Zimmermann 2005). Final models were grouped according to three predictor sets, i.e., environmental, historical, and overall models (all variables mixed). In all presented models only significant variables $(p<0.05)$ were included. All linear models were performed using R version 3.0.3 (R Development Core Team 2014).

\section{Results}

Of the total of 5665 ha of WKHs identified in the study area, $46 \%$ referred to stands with forest continuity between 100 and 220 years (Table 2, column Total). In comparison, only $38.9 \%$ of all forests in Zemgale belong to these forest continuity classes. Accordingly, WKHs were counted more often in forests with continuity between 100 and 220 years and were clearly less frequently represented in forests with continuity less than 100 years (Fig. 2a). Proportions of WKHs in boreal and early successional forests of different continuity classes amounted to $2.0-6.2 \%$ (Table 2; Fig. 2b), which corresponds fairly well with the average proportion of WKHs (3.8\%) in all forests. In contrast, WKHs dominated by nemoral tree species and black alder accounted for 10.8-23.0\% of the total area of these 
Table 2 Areas of forest and WKHs at the stand scale (S0), arranged by forest continuity classes and forest vegetation classes

\begin{tabular}{|c|c|c|c|c|c|}
\hline Classes & $\begin{array}{l}\text { Boreal } \\
\text { forests }\end{array}$ & $\begin{array}{l}\text { Early succession } \\
\text { forests }\end{array}$ & $\begin{array}{l}\text { Black alder } \\
\text { wetland forests }\end{array}$ & $\begin{array}{l}\text { Nemoral } \\
\text { forests }\end{array}$ & Total \\
\hline All forests (ha) & 71,237 & 65,571 & 5726 & 4647 & $1,471,181$ \\
\hline (\% of all forests) & 48.4 & 44.5 & 3.9 & 3.2 & 100 \\
\hline WKHs (ha) & 1778 & 2293 & 843 & 751 & 5665 \\
\hline (\% of all WKHs) & 31.4 & 40.5 & 14.9 & 13.2 & 100 \\
\hline $\begin{array}{l}\text { (\% of forest vegetation } \\
\text { class) }\end{array}$ & 2.5 & 3.5 & 14.7 & 16.2 & 3.8 \\
\hline \multicolumn{6}{|l|}{ Continuity classes } \\
\hline \multicolumn{6}{|l|}{ 1. $<100$ years } \\
\hline Forests (ha) & 19,999 & 29,952 & 2154 & 1892 & 53,997 \\
\hline (\% of all forests) & 28.1 & 45.7 & 37.6 & 40.7 & 36.7 \\
\hline WKHs (ha) & 445 & 638 & 233 & 223 & 1539 \\
\hline (\% of all WKHs) & 7.9 & 11.3 & 4.1 & 3.9 & 27.2 \\
\hline (\% of class area) & 2.2 & 2.1 & 10.8 & 11.8 & 2.9 \\
\hline (\% of all forests) & 0.6 & 1.0 & 4.1 & 4.8 & 1.1 \\
\hline \multicolumn{6}{|l|}{ 2. $100-149$ years } \\
\hline Forests (ha) & 10,643 & 10,868 & 1275 & 602 & 23,388 \\
\hline (\% of all forests) & 14.9 & 16.6 & 22.3 & 13.0 & 15.9 \\
\hline WKHs (ha) & 335 & 453 & 184 & 93 & 1065 \\
\hline (\% of all WKHs) & 5.9 & 8.0 & 3.3 & 1.6 & 18.8 \\
\hline (\% of class area) & 3.2 & 4.2 & 14.4 & 15.5 & 4.5 \\
\hline (\% of all forests) & 0.5 & 0.7 & 3.2 & 2.0 & 0.7 \\
\hline \multicolumn{6}{|l|}{ 3. $150-220$ years } \\
\hline Forests (ha) & 17,561 & 13,519 & 1644 & 1089 & 33,813 \\
\hline (\% of all forests) & 24.7 & 20.6 & 28.7 & 23.4 & 23.0 \\
\hline WKHs (ha) & 528 & 504 & 276 & 233 & 1541 \\
\hline (\% of all WKHs) & 9.3 & 8.9 & 4.9 & 4.1 & 27.2 \\
\hline (\% of class area) & 3.0 & 3.7 & 16.8 & 21.4 & 4.6 \\
\hline (\% of all forests) & 0.7 & 0.8 & 4.8 & 5.0 & 1.1 \\
\hline \multicolumn{6}{|l|}{ 4. $>220$ years } \\
\hline Forests (ha) & 23,034 & 11,232 & 653 & 1064 & 35,983 \\
\hline (\% of all forests) & 32.3 & 17.1 & 11.4 & 22.9 & 24.4 \\
\hline WKHs (ha) & 470 & 698 & 150 & 202 & 1520 \\
\hline (\% of all WKHs) & 8.3 & 12.3 & 2.6 & 3.6 & 26.8 \\
\hline (\% of class area) & 2.0 & 6.2 & 23.0 & 19.0 & 4.2 \\
\hline (\% of all forests) & 0.7 & 1.0 & 2.6 & 4.4 & 1.0 \\
\hline
\end{tabular}

two vegetation classes, with largest values in forests of higher continuity classes. Accordingly, WKHs were not evenly distributed with respect to forest vegetation and forest continuity classes.

The presence of WKHs positively correlated with areas that had been afforested between 1790 and 1860 and between 1860 and 1910 (Figs. 3, 4, 5). As demonstrated by using small and broad scale displays (S1 and S4; Fig. 3), changes in forest cover strongly 

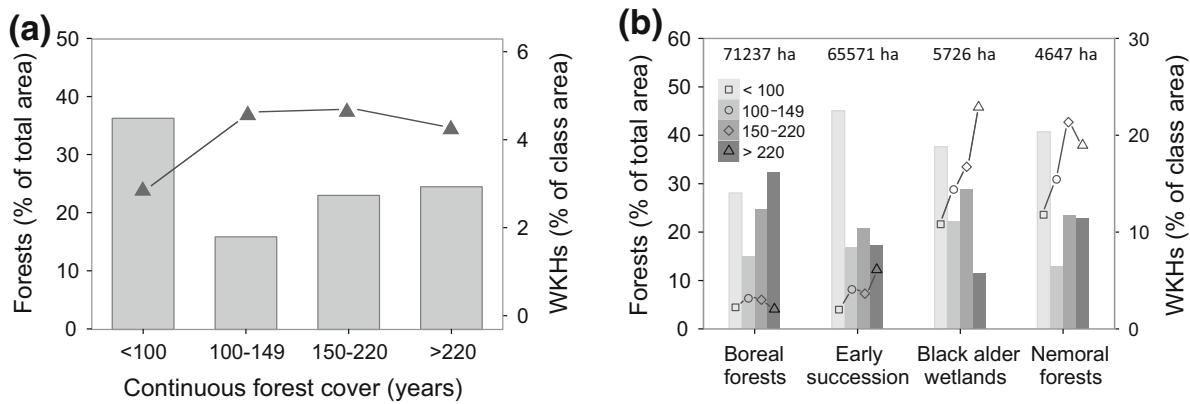

Fig. 2 a Proportion of forest area (bars) and woodland key habitats (WKHs, triangles) at the stand scale (S0) and arranged by the four forest continuity classes. b Proportion of forest area (bars) and WKH area (symbols) at the stand scale ( $\mathrm{S} 0$ ) and in each of the forest continuity classes, arranged by the four forest vegetation classes (see Methods for definitions). Numbers at the top indicate the total area of forests in each of the forest vegetation classes. The lines are used to guide the eyes

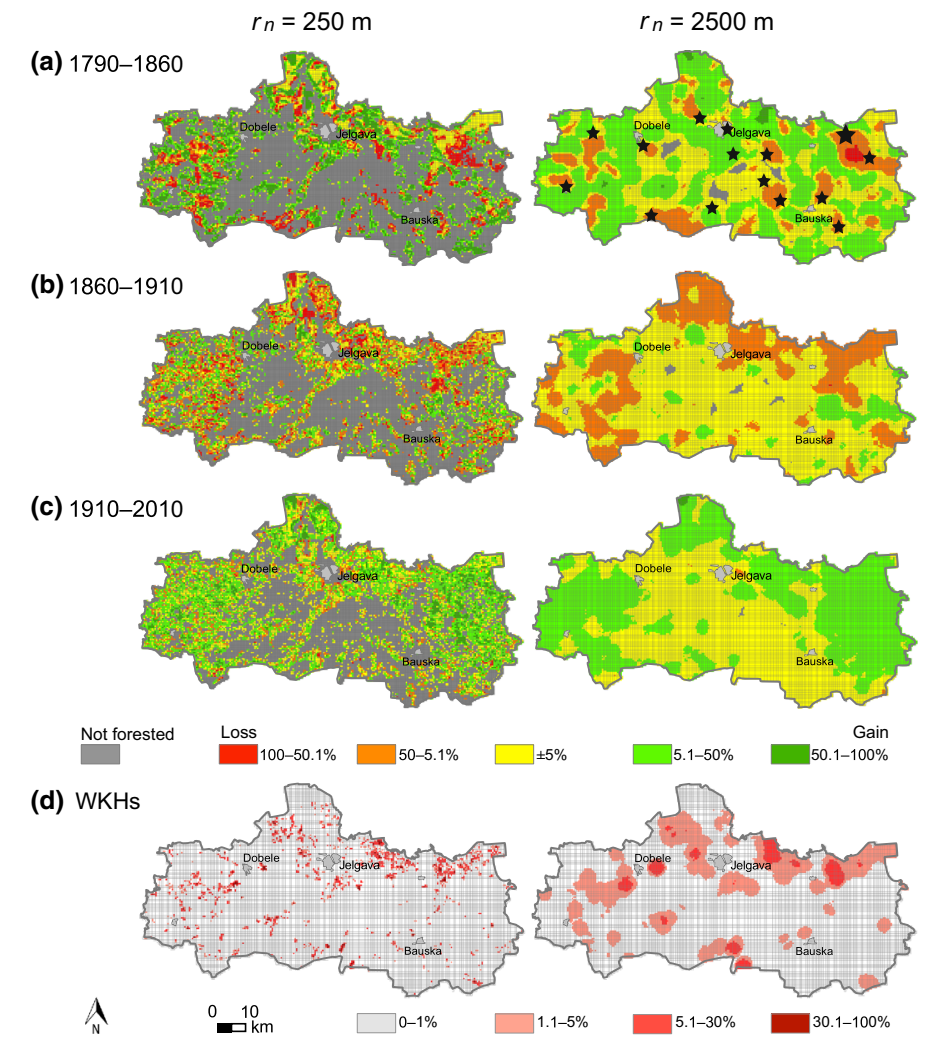

Fig. 3 a-c Spatial distribution of forest cover changes at scales $\mathrm{S} 1$ (neighbourhood radius $r_{\mathrm{n}}=250 \mathrm{~m}$ ) and $\mathrm{S} 4\left(r_{\mathrm{n}}=2500 \mathrm{~m}\right)$ from 1790 to 2010 . Gain and loss refer to the percent change in the corresponding gridcells. Stars denote locations of old manufacturing centres before industrialization in the 19th century. d Spatial distribution and proportion of WKHs, with percentages referring to grid-cells of $500 \times 500 \mathrm{~m}$ 
(a)

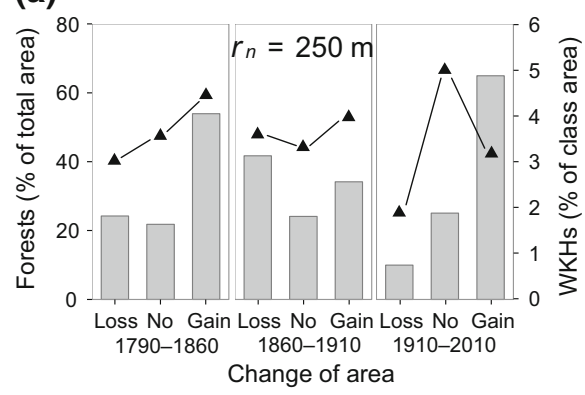

(b)

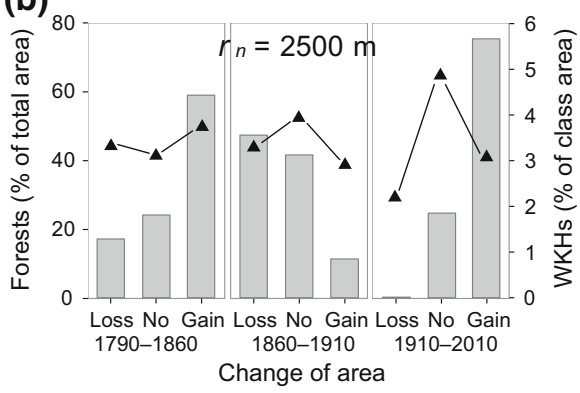

Fig. 4 Forest area changes (loss, no change, gain) as a percent of total forest area (bars), and WKHs area changes normalized to forest area changes (triangles) at scales $\mathrm{S} 1$ (neighbourhood radius $r_{\mathrm{n}}=250 \mathrm{~m}$ ) and $\mathrm{S} 4\left(r_{\mathrm{n}}=2500 \mathrm{~m}\right)$ and from 1790 to 2010 . Loss: $-100 \%$ to $-5.1 \%$; no change: $-5 \%$ to $+5 \%$; gain: $+5.1 \%$ to $+100 \%$. The lines are used to guide the eyes

varied, i.e., with change rate values of $-100 \%$ (deforestation, forest loss) to $+100 \%$ (afforestation, forest gain). Vast deforestation of large areas was more characteristic from 1790-1910 (at scale S4: 18\% of total area from 1790-1860 and almost half of the total area from 1860-1910; Figs. 3 (red areas), 4b). In general, landscapes with a deforestation rate (loss: -100 to $-5.1 \%$ ) hosted a smaller proportion of WKHs (by $26 \%$ at S1 and by $12 \%$ at S4; Fig. 4), compared to areas with afforestation (gain: +5.1 to $+100 \%$ ). Highest proportions of WKHs were found in areas with high afforestation rate from 1790 to 1910 at scale (S1), and in landscapes with constant forest cover since 1910 (S1, S4).

\section{Univariate analysis}

Correlation coefficients between predictor variables and WKHs varied considerably across scales (Fig. 5). At the stand scale (S0), old forests (OLDF, $p<0.001$ ), and tree species richness (TRICH, $p<0.01$ ) had the highest coefficients, though these values were relatively low. At landscape scales S2 and S3, peak values were found for forest cover in earlier reference years (F1790, F1860, F1910, $p<0.001$ ), old forests (OLDF, $p<0.001$ ), tree species richness (TRICH, $p<0.001$ ), and number of forest patches in earlier reference years (NP1790, NP1860, NP1910, $p<0.01$ ). Coefficients of patch density (PD1790, PD1860, PD1910), forest cover changes (CH12, CH23, CH34), and glades (GLADES) increased with scale. Positive and relatively high coefficients persisted for the number of forest patches (NP1790, NP1860, NP1910), and lengths of rivers and streams (RIVERS) at the broadest scales (S3, S4). Correlation coefficients for forest continuity (CONT) peaked at landscape scales (S1, S2). Remarkably, current patch density (PD2010, $p<0.01$ ) had the most negative coefficients with WKHs at landscape scales (S1, S2). While current patch density (PD) was negatively correlated with the presence of WKHs at smaller landscape scales, clearly positive values resulted at broader scales and with earlier reference years (Figs. 5, 6).

\section{Multivariate analysis}

At the scale of stands (S0), old forests (OLDF), tree species richness (TRICH), and forest continuity $(\mathrm{CONT})$ were most important in regression models $\left(D^{2}=0.19\right.$, overall model at 


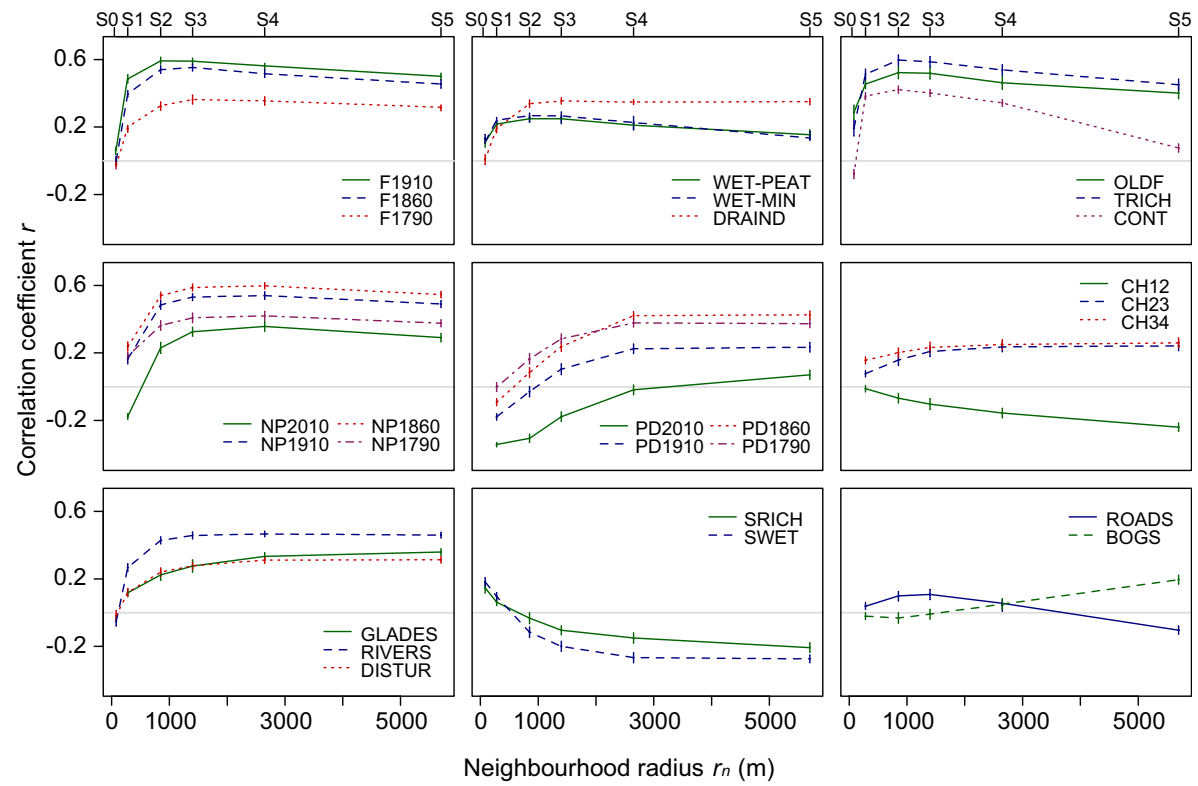

Fig. 5 Best correlations of single variables with WKHs (Pearson's coefficient) as mean values (symbols) and $95 \%$ confidence intervals (vertical bars), based on 100 model runs

Table 3 Best GLMs for the presence of WKHs at various scales

\begin{tabular}{|c|c|c|c|c|}
\hline Model & $\begin{array}{l}\text { Residual } \\
\text { deviance }\end{array}$ & $D^{2}\left(D_{\mathrm{all}}^{2}\right)$ & $\begin{array}{l}\% \text { change } \\
\text { in } D^{2}\end{array}$ & AIC \\
\hline \multicolumn{5}{|l|}{ Historical models } \\
\hline S0 F1910 + CONT & 1195 & $0.04(0.05)$ & 0.01 & 3017 \\
\hline $\mathrm{S} 1 \mathrm{CONTm}+\mathrm{F} 1910 \mathrm{~m}+\mathrm{CH} 23 \mathrm{~m}$ & 907 & $0.27(0.32)$ & 0.05 & 2723 \\
\hline S2 F1910 m + F1790sd & 837 & $0.33(0.38)$ & 0.02 & 2649 \\
\hline S3 F1910 m + F1790sd + CH34 m & 807 & $0.35(0.39)$ & 0.01 & 2623 \\
\hline S4 F1910sd + CH34 m & 740 & $0.41(0.44)$ & 0.02 & 2552 \\
\hline \multicolumn{5}{|l|}{ Environmental models } \\
\hline S0 OLDF + TRICH & 1022 & $0.18(0.23)$ & 0.02 & 2834 \\
\hline S1 OLDFm + TRICHm & 862 & $0.31(0.36)$ & 0.09 & 2674 \\
\hline $\mathrm{S} 2 \mathrm{OLDFm}+\mathrm{TRICHm}$ & 814 & $0.35(0.39)$ & 0.08 & 2626 \\
\hline S3 OLDFsd + RIVERSm + BOGSm & 795 & $0.36(0.41)$ & 0.02 & 2611 \\
\hline S4 OLDFsd + BOGSm + DISTURsd - SRICHsd & 713 & $0.43(0.47)$ & 0.01 & 2533 \\
\hline \multicolumn{5}{|l|}{ Overall models } \\
\hline SO OLDF + TRICH + CONT & 1010 & $0.19(0.23)$ & 0.01 & 2826 \\
\hline S1 OLDFm + CONTm + TRICHm & 842 & $0.33(0.37)$ & 0.02 & 2658 \\
\hline S2 OLDFm + TRICHm + F1910 m & 794 & $0.36(0.40)$ & 0.01 & 2610 \\
\hline S3 OLDFsd + RIVERSm + BOGSm + CH34 m & 782 & $0.37(0.40)$ & 0.01 & 2602 \\
\hline $\mathrm{S} 4$ OLDFsd + BOGSm + CH34 m & 697 & $0.44(0.49)$ & 0.01 & 2513 \\
\hline
\end{tabular}

Models (negative binomial method) were produced for WKH presence in woodlands using datasets of 3700 grid-cells ( $\mathrm{n}=100$; derived from two datasets using random unit selections; see Methods); $m$ mean, $S D$ standard deviation. A change in deviance $D^{2}<1 \%$ was used as a stopping criterion. Null deviance $=1248$. Signs indicate the variable's slopes. Deviances $D^{2}$ are indicated for best models and for full models including all variables of corresponding scales (in brackets) 
S0). However, these variables had very low explanatory power for the historical model $\left(D^{2}=0.04\right)$ and modest power for the environmental model $\left(D^{2}=0.18\right.$; Table 3$)$. With increasing scale in historical models, forest cover in 1910 (F1910) and forest cover change from 1790 to 1860 (CH34) increased in importance, with the greatest deviance of $D^{2}=0.41$ at scale S4. In environmental models, OLDF was highly influential at all scales. In addition, variables indicating landscape heterogeneity, such as forest disturbances (DISTUR), soil fertility (SRICH, negative sign), and the proximity of bogs (BOGS), contributed to high explanatory power at broad scales $\left(\mathrm{S} 4: D^{2}=0.43\right)$. For all scales, the explanatory power of overall models with mixed variables did only slightly exceed that of the models with exclusively historical or environmental variables. At the broadest scales, landscape elements such as BOGS and RIVERS contributed to models with the highest explanatory power $(\mathrm{S} 3, \mathrm{~S} 4)$.

\section{Discussion}

\section{Forest continuity and woodland key habitats}

The presence of old-growth dependent species in small and dispersed/isolated forest stands inside of intensively managed landscapes suggests that there has been continuity of tree cover over a long period (Nordén and Appelqvist 2001; Sverdrup-Thygeson et al. 2014). Classical groups of old-growth species such as lichens or mosses are sensitive to an interruption in forest continuity, resulting in, e.g., the lack of preferred or host tree species or the long-lasting lack of suitable substrate or habitat (Peterken 1996; Fedrowitz et al. 2012). As well, some of these species require a long time to colonize (Fritz et al. 2008; Singh et al. 2015). Since the criteria for designation of a WKH were based on the presence of old-growth species and structures, we expected that WKHs would be mainly linked to the long-term forest cover in a given site. However, at the stand scale, only one fourth of the WKHs (see Table 2) were located in woodlands with continuous forest cover for more than 220 years. In most areas (73.2\%), variables other than long-term forest continuity accounted for the formation of WKHs, as reported also in studies in Sweden (Ericsson et al. 2005; Jönsson et al. 2009) and Finland (Pykälä 2007). This considerable percentage may be explained by the variety of forest structure definitions (McElhinny et al. 2005), the insufficient knowledge about the traits of WKH indicator species (Liira et al. 2014), as well as by uneven distributions of forest vegetation classes and successional stages. Indeed, a high proportion of WKHs (40.5\%; see Table 2) corresponded to early successional forests, with the fast-growing and fast-decaying species of genera Betula and Populus. These tree species develop rapidly on abandoned agricultural land and form diverse forest structures within only several decades, such as gaps for plants, dead wood for fungi, mosses and dwelling arthropods (Madžule et al. 2012). Regarding agricultural land in particular, a considerable amount (27.2\%) of the Zemgale's WKHs has formed on land used for agriculture only 100 years ago. Long-term continuous forest cover is more characteristic of black alder wetlands that have been mostly excluded from agriculture, while habitats with the nemoral deciduous tree species Quercus robur, Fraxinus excelsior, Ulmus glabra and Tilia cordata are often secondary and thus 'younger'. Another reason for the high percentage of WKHs in recently developed forests is that, to a considerable extent, many of these forests developed on drained bogs, old parks around manors, wooded meadows, abandoned dwelling houses with traditional tree plantings, and avenues, none of which 
were depicted as forest cover on old maps (Fescenko et al. 2014). As recently found, old rural parks (Lõhmus and Liira 2013) and abandoned wooded meadows (Vojta and Drhovská 2012) could have even higher habitat values than long-term preserved forest remnants.

At the landscape scales, changes in forest cover clearly pointed to landscape dynamics with a highly varying ratio of agricultural and forested area over time. These changes were spatially and temporally hierarchical. This finding was demonstrated at scale S4 with $r_{\mathrm{n}}=2500 \mathrm{~m}$, where forest cover changes corresponded best to our time step of 50-100 years, whereas scale S1 was obviously too small to detect significant trends (see Fig. 3). At scale S4, the highest density of WKHs corresponded to areas covered by large forest patches 100-150 years ago. Most of these patches were heavily affected by human activities, with dynamic internal land-use changes and disturbances caused by fire and logging (Zunde 1999), both of which promoted small-scale heterogeneity. Large regions of deforestation in 1790-1860 mainly resulted from the need for wood by manufacturing facilities. For example, the large area with more than $50 \%$ forest loss in the northeast part of the study area (see Fig. 3a) clearly corresponded to the largest iron manufacturing centre Dzelzamurs of Duchy of Courland/Semigallia, where iron-works ran from 1648 to 1705 and longer. Nowadays, this area has one of the highest densities $(5.1-30 \%)$ of WKHs in Zemgale. Such an evolution from historic anthropogenic disturbance to old-growth or natural forest parks has been described for many places (e.g., Pyle 1988; Kupper 2014). The fact that a significant part of the WKHs is concentrated in landscapes that underwent intense deforestation between 1790 and 1910 also agrees with the forest continuity analysis at the scale of stands (S0). Obviously, the presence of WKHs as an indicator of increased biodiversity translates to land-use temporal heterogeneity, which is in line with several studies that have pointed to the legacy of land use as an important driver of today's diversity at various scales (Lunt and Spooner 2005; Fischer et al. 2006; Wohlgemuth et al. 2008a; Boucher et al. 2014). To a considerable extent, this is in accordance with the natural woodlands multi-scale heterogeneity theory that puts forward the importance of habitat heterogeneity created by natural disturbances and successional processes (Angelstam and Kuuluvainen 2004). The documented land-use changes at small landscape scales regarding the short non-forest time gap (50-70 years) may be considered intermediate in terms of disturbance frequency and intensity. Accordingly, species richness and diversity may increase in various communities (Connell 1978; Grman et al. 2015), and in particular also in forests (Wohlgemuth et al. 2002). However, our results emphasize also the importance of old forest fragments throughout the landscape that function as species sources in fragmented landscapes (Hanski 1999; Wulf 2003). Both elements, a relatively short period without forest cover and a continuous proximity of old forest patches with high structure quality seems sufficient for successful re-colonization, even for old-growth dependent species (see Vellak and Paal 1999; Madžule et al. 2012 for mosses; Liira et al. 2014 for forest-dwelling plants). Thus, long-term forest continuity only partly covers habitat requirements for WKHs. Our analysis of forest cover changes during the last two centuries reveals a surprisingly diverse and dynamic land-use history in places that have been designated as WKHs. We therefore can reject our first hypothesis claiming that long-term forest continuity is the most important predictor of WKH presence.

\section{Scale dependence of predictor variables}

Several studies have demonstrated that the variability in ecological communities and ecosystems is spatially structured, and that this holds for abiotic and biotic factors, and 
therefore also for biodiversity (e.g., Wagner 2003; Franc et al. 2007; Götmark et al. 2008, 2011). According to Wiens (1989), predictability is higher at broad spatial and temporal scales. In agreement, our variables at broad scales explained WKH presence more accurately (max. 44\%) than the variables at small scales, such as at the habitat level (max. $19 \%$ ). Our study demonstrates as well that scale considerations change not only the predictive power of variables, but also their character. We found that local environmental factors that directly influence species presence and growth performance (site conditions, tree species age and richness) were most significant at small and intermediate scales, i.e., from stand (S0) to landscape scales (S1, S2). At broader scales (S3, S4), correlations were strongest with variables indicating landscape heterogeneity: forest cover changes, forest disturbances, forest fragmentation, rivers, streams, bogs, ditches, forest meadows and glades. The significance of all these variables increased with scale, pointing to the relevance of landscape heterogeneity for small-scale biodiversity (Levin 2000; Dufour et al. 2006; Münkemüller et al. 2014; Bailey et al. 2017).

Interestingly, correlations involving patch density changed not only over spatial scales (with negative values at smaller scales and positive values at broader scales), but also over time. In particular, the rate and the character of the correlation coefficients increased in a similar way (see Fig. 6). In essence, forest fragmentation in distant past converged with broad-scale patch density, and forest fragmentation in recent past corresponded to smallscale patch density. This suggests that temporal heterogeneity resembles the ecological pattern indicated by spatial heterogeneity, which raises a question about the interrelation of processes and the resulting patterns. Such a relationship between spatial and temporal scales is described in the theory of panarchies (Holling 2001; Allen et al. 2014), though without quantitative data analysis. Our finding also suggests that historical eras affected landscapes at broad scales, whereas 'recent' small-scale disturbances due to extreme events and biological interactions were most influential at the habitat scale. Observations have already been made that species colonization rates and turnover in space and time exhibit

Fig. 6 Correlogram of WKHs presence versus forest patch density across spatio-temporal scales. The $\mathrm{x}$-axis represents patch density across spatial scale referring to neighbourhood radius $r_{\mathrm{n}}$; the $\mathrm{y}$-axis represents patch density over time regarding the difference between the year of the present WKH pattern and the reference year of the land-use information. All correlation coefficients are with $p<0.02$

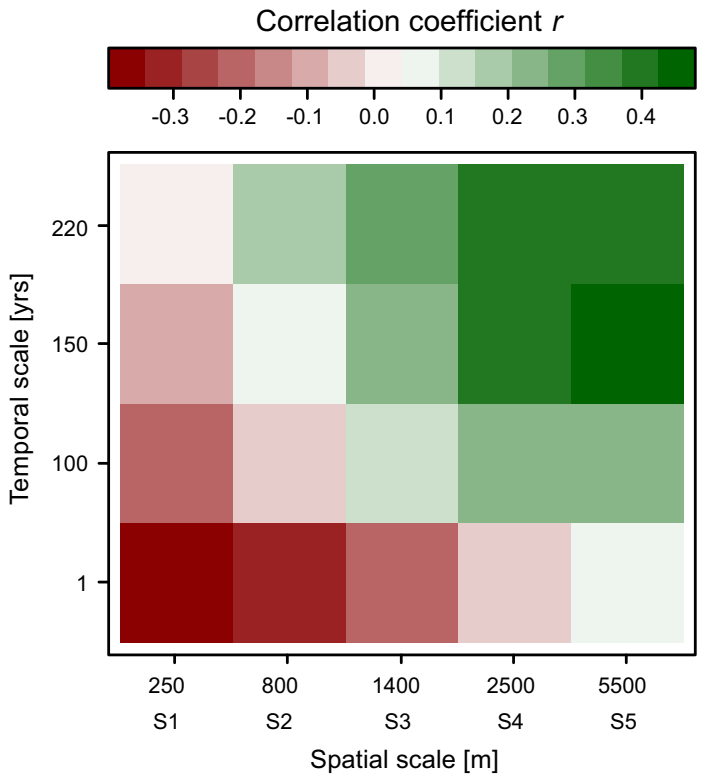


similar scale dependencies of habitat heterogeneity (Scheiner et al. 2011), biogeographical processes (Cavender-Bares et al. 2009) and environmental gradients (Soininen 2010). Case studies on the convergence of spatial and temporal disturbance events are scarce (Turner et al. 1998; White and Jentsch 2001; Bolliger et al. 2007); the subject, however, deserves more attention, in particular, regarding sustainable ecosystem dynamics in the complex systems of people and nature (e.g., Angeler et al. 2016).

Our results also confirm some shifts in combined effects of predictor variables of WKHs at different spatial scales. The derived GLMs show, especially at broader scales, the impact of variables that are hidden (i.e., not significant) at smaller scales, e.g., the importance of adjacent bogs. An increase in forest disturbances (DISTUR) and proximity of bogs likely stimulate WKH species communities by amplifying microhabitat heterogeneity and environmental processes. The relevance of forest disturbances at broader scales might as well be a statistical effect because WKHs are defined to be located in undisturbed forests. With increasing scale, such areas must include more forest disturbance sites as a function of the larger areas considered (Cavender-Bares et al. 2009). However, a large number of papers demonstrate a positive influence of disturbances on the diversity of insects (e.g., Bouget and Duelli 2004), vascular plants (e.g., Wohlgemuth et al. 2008b), tree species (e.g., Boucher et al. 2014) and many more taxa (e.g., Thom and Seidl 2016). Regarding historical models, the most important were variables directly linked to old-growth attributes, such as forest continuity and forest cover for at least 100 years, as well as forest area dynamics more than 100 years ago. Stands designated as WKHs were primarily formed in the large old woodland matrix, irrespective of the duration of interior forest continuity. This underpins the importance of landscape continuity as a long-term matrix for spatially dispersed key habitat patches. Biodiversity management should thus emphasize the integration of new habitat fragments, such as middle-aged or mature stands and/or bog-forest edges, as well as settlement-forest edges, as a potential source of biodiversity. In this respect, a definition of additional WKHs may render biodiversity conservation more dynamic, for example by establishing a dense network of WKHs with varying ages and structures, which is in line with results from tests of the SLOSS theory (single large or several small; reviewed by Fahrig 2013).

\section{Conclusions}

Woodland key habitats in a landscape of the Baltic region represent not only old-growth forests but also past land-use dynamics caused by multiple disturbances that have resulted in structural and taxonomical diverse forest stands. At small scales (S0, S1), the presence of WKHs correlates best with local site factors, as well as with small-scale and short-term gaps in the past forest cover. At broader scales, WKHs correlate best with landscape spatial heterogeneity and habitat richness. To some extent, the last two hundred years of human presence, such as settlement activities and intermediate logging, have replaced natural disturbances in this region as the principal agent of dynamics in forests.

Scale considerations uncover the dynamic importance of factors affecting habitats and landscapes. Here, temporal habitat fluctuations resemble the ecological pattern of spatial heterogeneity, which implies that future land management should aim at dynamically maintaining various disturbance elements in the forests. Accordingly, it is important to have not only conventional protected old forest areas with long-term forest continuity, but a set of structurally rich forests at broader scales that resembles past natural or anthropogenic disturbance regimes. 
Acknowledgements We thank Guntis Brūmelis and two anonymous reviewers for helpful comments, Juris Zarinš̌ for providing access to the SFS database, and Melissa Dawes for correcting the English text.

\section{References}

Allen CR, Angeler DG, Garmestani AS, Gunderson LH, Holling CS (2014) Panarchy: theory and application. Ecosystems 17:578-589

Amici V, Landi S, Frascaroli F, Rocchini D, Santi E, Chiarucci A (2015) Anthropogenic drivers of plant diversity: perspective on land use change in a dynamic cultural landscape. Biodivers Conserv 24:3185-3199

Angeler DG, Allen CR, Garmestani AS, Gunderson LH, Linkov I (2016) Panarchy use in environmental science for risk and resilience planning. Environ Syst Decis 36:225-228

Angelstam P, Kuuluvainen T (2004) Boreal forest disturbance regimes, successional dynamics and landscape structures: a European perspective. Ecol Bull. doi:10.2307/20113303

Bailey JJ, Boyd DS, Hjort J, Lavers CP, Field R (2017) Modelling native and alien vascular plant species richness: At which scales is geodiversity most relevant? Global Ecol Biogeogr. doi:10.1111/geb.12574

Bolker BM, Brooks ME, Clark CJ (2009) Generalized linear mixed models: a practical guide forest ecology and evolution. Trends Ecol Evol 24:127-135

Bolliger J, Wagner HH, Turner MG (2007) Identifying and quantifying landscape patterns in space and time. In: Kienast $\mathrm{F}$ et al (eds) A changing world. Challenges for landscape research. Springer, Netherlands, pp 177-194

Boscolo D, Metzger JP (2009) Is bird incidence in Atlantic forest fragments influenced by landscape patterns at multiple scales? Landscape Ecol 24:907-918

Boucher Y, Grondin P, Auger I (2014) Land use history (1840-2005) and physiography as determinants of southern boreal forests. Landscape Ecol 29:437-450

Bouget C, Duelli P (2004) The effects of windthrow on forest insect communities: a literature review. Biol Conserv 118:281-299

Braun-Blanquet J (1964) Pflanzensoziologie: Grundzüge der Vegetationskunde. Springer, Wien

Cadotte MW, Barlow J, Nuñez MA, Pettorelli N, Stephens PA (2017) Solving environmental problems in the Anthropocene: the need to bring novel theoretical advances into the applied ecology fold. J Appl Ecol 54:1-6

Cavender-Bares J, Kozak KH, Fine PV, Kembel SW (2009) The merging of community ecology and phylogenetic biology. Ecol Lett 12:693-715

Connell JH (1978) Diversity in tropical rain forests and coral reefs. Science 199:1302-1310

Dufour A, Gadallah F, Wagner HH, Guisan A, Buttler A (2006) Plant species richness and environmental heterogeneity in a mountain landscape: effects of variability and spatial configuration. Ecography 29:573-584

Dunsdorf E, Spekke A (1964) History of Latvia 1500-1600. Daugava, Stockholm

Ek T, Susko U, Auzins R (2002) Inventory of woodland key habitats. Methodology. Latvian State Forest Service \& Regional Forestry Board of Östra Götaland, Sweden, pp. 73

Envirotech (2013) GIS Latvija. Available from http://www.envirotech.lv/index.php?v=2 (accessed January 2013)

Ericsson T, Berglund H, Östlund L (2005) History and forest biodiversity of woodland key habitats in south boreal Sweden. Biol Conserv 122:289-303

Ernoult A, Tremauville Y, Cellier D (2006) Potential landscape drivers of biodiversity components in a flood plain: past or present patterns? Biol Conserv 127:1-17

European Soil Database (2013) Institute for Environment and Sustainability. Available from http://eusoils. jrc.ec.europa.eu/ESDB_Archive/ESDB/(accessed January 2013)

Fahrig L (2013) Rethinking patch size and isolation effects: the habitat amount hypothesis. J Biogeogr 40:1649-1663

Fedrowitz K, Kuusinen M, Snäll T (2012) Metapopulation dynamics and future persistence of epiphytic cyanolichens in a European boreal forest ecosystem. J Appl Ecol 49:493-502

Fescenko A, Nikodemus O, Brūmelis G (2014) Past and contemporary changes in forest cover and forest continuity in relation to soils (Southern Latvia). Pol J Ecol 62:625-638

Fescenko A, Lukins M, Fescenko I (2016) Validation of medium-scale historical maps of southern Latvia for evaluation of impact of continuous forest cover on the present-day mean stand area and tree species richness. Baltic For 22(1):51-62 
Fischer J, Lindenmayer DB, Manning AD (2006) Biodiversity, ecosystem function, and resilience: ten guiding principles for commodity production landscapes. Front Ecol Environ 4:80-86

Foley JA, DeFries R, Asner GP, Barford C, Bonan G, Carpenter SR, Chapin FS, Coe MT, Daily GC, Gibbs HK, Helkowski JH, Holloway T, Howard EA, Kucharik CJ, Monfreda C, Patz JA, Prentice IC, Ramankutty N, Snyder PK (2005) Global consequences of land use. Science 309:570-574

Franc N, Götmark F, Økland B (2007) Factors and scales potentially important for saproxylic beetles in temperate mixed oak forest. Biol Conserv 135:86-98

Fritz Ö, Gustafsson L, Larsson K (2008) Does forest continuity matter in conservation? -A study of epiphytic lichens and bryophytes in beech forests of southern Sweden. Biol Conserv 141:655-668

Gerhardt F, Foster DR (2002) Physiographical and historical effects on forest vegetation in central New England. USA. J. Biogeogr 29:1421-1437

Götmark F, von Proschwitz T, Franc N (2008) Are small sedentary species affected by habitat fragmentation? Local vs. landscape factors predicting species richness and composition of land molluscs in Swedish conservation forests. J Biogeogr 35:1062-1076

Götmark F, Asegård E, Franc N (2011) How we improved a landscape study of species richness of beetles in woodland key habitats, and how model output can be improved. Forest Ecol Manag 262:2297-2305

Graham CH, VanDerWal J, Phillips SJ, Moritz C, Williams SE (2010) Dynamic refugia and species persistence: tracking spatial shifts in habitat through time. Ecography 33:1062-1069

Grman E, Orrock JL, Habeck CW, Ledvina JA, Brudvig LA (2015) Altered beta diversity in post-agricultural woodlands: two hypotheses and the role of scale. Ecography 38:614-621

Hanski I (1999) Metapopulation ecology. Oxford University Press, Oxford

Holling CS (2001) Understanding the complexity of economic, ecological, and social systems. Ecosystems 4:390-405

Hytteborn H, Maslov AA, Nazimova DI, Rysin LP (2005) Boreal forests of Eurasia. In: Andersson F (ed) Coniferous forests, Ecosystems of the World, vol 6. Elsevier, Amsterdam, pp 23-99

Ikauniece S, Brūmelis G, Zarinš J (2012) Linking woodland key habitat inventory and forest inventory data to prioritize districts needing conservation efforts. Ecol Indic 14:18-26

Jönsson MT, Fraver S, Jonsson BG (2009) Forest history and the development of old-growth characteristics in fragmented boreal forests. J Veg Sci 20:91-106

Josefsson T, Olsson J, Östlund L (2010) Linking forest history and conservation efforts: long-term impact of low-intensity timber harvest on forest structure and wood-inhabiting fungi in northern Sweden. Biol Conserv 143:1803-1811

Kaplan J, Krumhardt K, Zimmermann N (2009) The prehistoric and preindustrial deforestation of Europe. Quaternary Sci Rev 28:3016-3034

Kasparinskis R, Nikodemus O (2012) Influence of environmental factors on the spatial distribution and diversity of forest soil in Latvia. Est J Earth Sci 61:48-64

Kupper P (2014) Creating wilderness: a transnational history of the Swiss National Park (Vol. 4). Berghahn Books, New York

Levin S (2000) Multiple scales and the maintenance of biodiversity. Ecosystems 3:498-506

Li H, Wu J (2004) Use and misuse of landscape indices. Landscape Ecol 19:389-399

Liira J, Jürjendal I, Paal J (2014) Do forest plants conform to the theory of island biogeography: the case study of bog islands. Biodivers Conserv 23:1019-1039

Lindborg R, Eriksson O (2004) Historical landscape connectivity affects present plant species diversity. Ecology 85:1840-1845

Lindenmayer DB, Franklin JF, Fischer J (2006) General management principles and a checklist of strategies to guide forest biodiversity conservation. Biol Conserv 131:433-445

Lizuma L, Klavins M, Briede A, Rodinovs V (2007) Long-term changes of air temperatures in Latvia. In: Klavins M (ed) Climate CHANGE in Latvia. University of Latvia, Riga, pp 11-20

Lizuma L, Briede A, Klavins M (2010) Long-term changes of precipitation in Latvia. Hydrol Res 41:241-252

Lõhmus K, Liira J (2013) Old rural parks support higher biodiversity than forest remnants. Basic Appl Ecol $14: 165-173$

Luginbühl Y, Howard P (2016) Landscape and sustainable development: the French perspective. Routledge, Abingdon

Lunt I, Spooner P (2005) Using historical ecology to understand patterns of biodiversity in fragmented agricultural landscapes. J Biogeogr 32:1859-1873

Madžule L, Brūmelis G, Tērauds A, Zarinš̌ J (2012) Time needed to achieve sufficient richness of structural elements and bryophytes in deciduous forest stands. Environ Exp Biol 10:57-66

McCullagh P, Nelder JA (1989) Generalized linear models. Chapman \& Hall, London 
McElhinny C, Gibbons P, Brack C, Bauhus J (2005) Forest and woodland stand structural complexity: its definition and measurement. Forest Ecol Manag 218:1-24

Metzger J, Martensen A, Dixo M (2009) Time-lag in biological responses to landscape changes in a highly dynamic Atlantic forest region. Biol Conserv 142:1166-1177

Münkemüller T, Gallien L, Lavergne S et al (2014) Scale decisions can reverse conclusions on community assembly processes. Global Ecol Biogeogr. doi:10.1111/geb.12137

Nordén B, Appelqvist T (2001) Conceptual problems of ecological continuity and its bioindicators. Biodivers Conserv 10:779-791

Noss R (1990) Indicators for monitoring biodiversity: a hierarchical approach. Conserv Biol 4:355-364

Palmer MW, Maurer TA (1997) Does diversity beget diversity? A case study of crops and weeds. J Veg Sci 8:235-240

Perhans K, Gustafsson L, Jonsson F (2007) Bryophytes and lichens in different types of forest set-asides in boreal Sweden. Forest Ecol Manag 242:374-390

Peterken GF (1996) Natural woodland. Ecology and conservation in northern temperate regions. Cambridge University Press, Cambridge

Pykälä J (2007) Implementation of Forest Act habitats in Finland: does it protect the right habitats for threatened species? Forest Ecol Manag 242:281-287

Pyle C (1988) The type and extent of anthropogenic vegetation disturbance in the Great Smoky Mountains before National Park Service acquisition. Castanea 53:183-196

R Development Core Team (2014) R: a language and environment for statistical computing. R Foundation for Statistical Computing, Vienna

Sala OE, Chapin FS, Armesto JJ, Berlow E, Bloomfield J, Dirzo R, Huber-Sanwald E, Huenneke LF, Jackson RB, Kinzig A, Leemans R, Lodge DM, Mooney H, Oesterheld M, Poff NL, Sykes MT, Walker BH, Walker M, Wall DH (2000) Global biodiversity scenarios for the year 2100. Science 287:1770-1774

Scheiner SM, Chiarucci A, Fox GA, Helmus MR, McGlinn DJ, Willig MR (2011) The underpinnings of the relationship of species richness with space and time. Ecol Monogr 81:195-213

Schneider DC (2009) Quantitative ecology: Measurement, models and scaling. Academic Press, San Diego

Schwarz M, Zimmermann N (2005) A new GLM-based method for mapping tree cover continuous fields using regional MODIS reflectance data. Remote Sens Environ 95:428-443

Singh G, Dal Grande F, Werth S, Scheidegger C (2015) Long-term consequences of disturbances on reproductive strategies of the rare epiphytic lichen Lobaria pulmonaria: clonality a gift and a curse. FEMS Microbiol Ecol 91:1-11

Soininen J (2010) Species turnover along abiotic and biotic gradients: patterns in space equal patterns in time? Bioscience 60:433-439

State Forest Service (2010) State Forest Register. Riga, Latvia

State Forest Service (2012) State Forest Register. Riga, Latvia

Sverdrup-Thygeson A, Gustafsson L, Kouki J (2014) Spatial and temporal scales relevant for conservation of dead-wood associated species: current status and perspectives. Biodivers Conserv 23:513-535

Thom D, Seidl R (2016) Natural disturbance impacts on ecosystem services and biodiversity in temperate and boreal forests. Biol Rev 91:760-781

Timonen J, Siitonen J, Gustafsson L et al (2010) Woodland key habitats in northern Europe: concepts, inventory and protection. Scand J Forest Res 25:309-324

Turner MG, Baker WL, Peterson CJ, Peet RK (1998) Factors influencing succession: lessons from large, infrequent natural disturbances. Ecosystems 1:511-523

Vellak K, Paal J (1999) Diversity of bryophyte vegetation in some forest types in Estonia: a comparison of old unmanaged and managed forests. Biodivers Conserv 8:1595-1620

Venables WN, Ripley BD (2013) Modern applied statistics with S-PLUS. Springer

Vojta J, Drhovská L (2012) Are abandoned wooded pastures suitable refugia for forest species? J Veg Sci 23:880-891

von Rauch G (1970) Die Geschichte der baltischen Staaten. W.Kohlhammer GmbH, Stuttgart

Wagner HH (2003) Spatial covariance in plant communities: integrating ordination, geostatistics, and variance testing. Ecology 84:1045-1057

Westphal C, Härdtle W, von Oheimb G (2004) Forest history, continuity and dynamic naturalness. In: Honnay O, Verheyen K, Bossuyt B, Hermy M (eds) Forest biodiversity: lessons from history for conservation, vol IUFRO Research Series 10. Cromwell Press, Trowbridge, pp 205-220

White PS, Jentsch A (2001) The search for generality in studies of disturbance and ecosystem dynamics. In: Esser K et al (eds) Progress in botany. Springer, Berlin Heidelberg, pp 399-450

Widerberg KM, Ranius T, Drobyshev I, Nilsson U, Lindbladh M (2012) Increased openness around retained oaks increases species richness of saproxylic beetles. Biodivers Conserv 21:3035-3059 
Wiens J (1989) Spatial scaling in ecology. Funct Ecol 3:385-397

Wohlgemuth T, Bürgi M, Scheidegger C, Schütz M (2002) Dominance reduction of species through disturbance-a proposed management principle for central European forests. Forest Ecol Manag 166:1-15

Wohlgemuth T, Moser B, Brändli U-B, Kull P, Schütz M (2008a) Diversity of forest plant species at the community and landscape scales in Switzerland. Plant Biosyst 142:604-613

Wohlgemuth T, Nobis MP, Kienast F, Plattner M (2008b) Modelling vascular plant diversity at the landscape scale using systematic samples. J Biogeogr 35:1226-1240

Wu J, Hobbs R (2002) Key issues and research priorities in landscape ecology: an idiosyncratic synthesis. Landscape Ecol 17:355-365

Wulf M (2003) Forest policy in the EU and its influence on the plant diversity of woodlands. J Environ Manage 67:15-25

Zunde M (1999) Dynamics of forest area and tree species composition, and their main driving factors. In: Strods H (ed) History of Latvian Forests until 1940. WWF, Riga, pp 111-203 